\section{SUMMARY}

1. Methods of preparation of three distinct fractions of histones have been described and applied to the thymus, spleen and liver of calves and to the liver and spleen of normal and leukaemic rats.

2. No differences in amino acid composition or in $N$-terminal groups of the same fractions from the different sources were found, outside the probable experimental errors. On the other hand the characteristic analytical differences between the fractions were apparent in all the preparations.

3. The purity of the fractions was examined by starch-gel electrophoresis. Apart from minor bands observed in some cases and probably due to unremoved impurities, no differences of the patterns or of the mobilities were observed which could be ascribed to tissue or species specificity.

4. Some qualification of the above statements are necessary for fractions derived from the Ehrlich ascites tumour. A complete resolution into the fractions was not achieved in this case.

We are indebted to the World Health Organization for the award of a Research Fellowship to one of us (L. H.) and to Dr V. Holoubek who made available the histones from leukaemic rat spleen and liver which he had prepared. We also wish to thank Dr D. M. P. Phillips for useful discussions. This investigation has been supported by grants to the Chester Beatty Research Institute, Institute of Cancer Research: Royal Cancer Hospital, from the Medical Research Council, the British Empire Cancer Campaign, the Jane Coffin Childs Memorial Fund for Medical Research, the Anna Fuller Fund, and the National Cancer Institute of the National Institutes of Health, U.S. Public Health Service.

\section{REFERENCES}

Butler, J. A. V., Davison, P. F., James, D. W. F. \& Shooter, K. V. (1954). Biochim. biophys. Acta, 13, 224. Chaveau, J., Moulé, Y. \& Rouiller, C. (1956). Exp. Cell Res. 11, 317.

Crampton, C. F., Moore, S. \& Stein, W. H. (1955). J. biol. Chem. 215, 787.
Crampton, C. F., Stein, W. H. \& Moore, S. (1957). J. biol. Chem. 225, 363.

Cruft, H. J., Mauritzen, C. M. \& Stedman, E. (1954). Nature, Lond., 174, 580.

Cruft, H. J., Mauritzen, C. M. \& Stedman, E. (1958). Proc. Roy. Soc. B, 149, 21.

Daly, M. M. \& Mirsky, A. E. (1955). J.gen. Physiol. 38, 405.

Davis, J. R. \& Busch, H. (1959). Cancer Res. 19, 1957.

Davison, P. F. (1957). Biochem. J. 66, 708.

Davison, P. F. \& Butler, J. A. V. (1954). Biochim. biophys. Acta, 15, 439.

Davison, P. F. \& Shooter, K. V. (1956). Bull. Soc. chim. Belg. 65, 85.

Hlavayová, E. (1957). Neoplasma, 4, 10.

Johns, E. W., Phillips, D. M. P., Simson, P. \& Butler, J. A. V. (1960). Biochem. J. 77, 631.

Johns, E. W., Phillips, D. M. P., Simson, P. \& Butler, J. A. V. (1961). Biochem. J. 80, 189.

Luck, J. M., Rasmussen, P. S., Satake, K. \& Tsvetikov, A. N. (1958). J. biol. Chem. 233, 1407.

Mauritzen, C. M. \& Stedman, E. (1959). Proc. Roy. Soc. B, $150,299$.

Mauritzen, C. M. \& Stedman, E. (1960). Proc. Roy. Soc. B, 153, 80.

Neelin, J. M. \& Butler, G. C. (1959). Canad. J. Biochem. Physiol. 37, 843.

Neelin, J. M. \& Butler, G. C. (1961). Canad. J. Biochem. Physiol. 39, 485.

Neelin, J. M. \& Connell, G. E. (1959). Biochim. biophys. Acta, 31, 539.

Neelin, J. M. \& Neelin, E. M. (1960). Canad. J. Biochem. Physiol. 38, 355.

Peterson, E. A. \& Sober, H. A. (1956). J. Amer. chem. Soc. 78, 751 .

Phillips, D. M. P. (1958). Biochem. J. 68, 35.

Phillips, D. M. P. \& Johns, E. W. (1959). Biochem. J. 72, 538.

Sanger, F. (1945). Biochem. J. 39, 507.

Schneider, J. H. (1958). J. biol. Chem. 233, 154.

Smithies, O. (1955). Biochem. J. 61, 629.

Starbuck, W. C. \& Busch, H. (1960). Cancer Res. 20, 891.

Stedman, E. \& Stedman, E. (1951). Phil. Trans. B, 235, 565.

Ui, N. (1957). Biochim. biophys. Acta, 25, 493.

Vendrely, R., Knobloch, A. \& Matsudaira, H. (1958). Nature, Lond., 181, 343.

Biochem. J. (1962) 82, 129

\title{
The Metabolism of 2-Fluoroethanol
}

\author{
By D. H. TREBLE \\ Department of Biochemistry, University of Cambridge
}

(Received 28 June 1961)

2-Fluoroethanol was first synthesized by Swarts (1914), but there was no report of its toxicity until its use as a rodenticide was patented in 1935 in Germany (Schrader, 1935). 2-Fluoroethanol has about the same toxicity as fluoroacetate to the rat and its structural relationship to this compound makes it likely that it is toxic for the same reason, namely as a substrate for a lethal synthesis of fluorocitrate (McCombie \& Saunders, 1946; Saunders, Stacy \& Wilding, 1949; Peters, 1952; Bartlett, Bioch. 1962, 82 
1952; Pattison, Howell, McNamara, Schneider \& Walker, 1956).

The present work is an attempt to confirm this hypothesis and to identify the enzyme systems responsible for the metabolism of 2 -fluoroethanol.

\section{EXPERIMENTAL}

Chemicals. All reagents were analytical-quality, and glass-distilled water was used throughout. 2-Fluoroethanol was kindly given by Dr B. C. Saunders. NAD and NADP were purchased from Sigma Chemical Co. Phenazine methosulphate was made by the method of Singer \& Kearney (1957).

Enzyme preparations. Crystalline horse-liver catalase and alcohol dehydrogenase were purchased from C. F. Boehringer und Soehne GmbH., Mannheim, Germany. Crude glucose oxidase was purchased from Sigma Chemical Co. Crude xanthine oxidase was prepared from fresh milk. After removing fat and casein with rennin, the enzyme was precipitated from the whey by the addition of solid ammonium sulphate $\left(293 \mathrm{~g} . / \mathrm{l}\right.$. at $\left.0^{\circ}\right)$. The precipitated enzyme was dried by dissolving in a fivefold volume of water at $0^{\circ}$, pouring into $10 \mathrm{vol}$. of acetone at $-15^{\circ}$ with vigorous stirring and immediately filtering on a Buchner funnel, precooled to $-15^{\circ}$. The acetone was washed through with 2 vol. of peroxide-free ether at $-15^{\circ}$. Solvents were removed under vacuum over phosphorus pentoxide and the white powder was stored at $-15^{\circ}$. Another alcohol dehydrogenase, of differing specificity from the enzyme crystallized by Bonnichsen \& Wassen (1948), was prepared from horse liver. The minced fresh horse liver was stirred in ice-cold water (1 1./500 g.) for $1 \mathrm{hr}$. at $2^{\circ}$ and filtered through muslin. The volume of the washed mince was restored with more water and the mixture homogenized in a blender for $2 \mathrm{~min}$. The suspension was brought to $52^{\circ}$ within $5 \mathrm{~min}$. and held at that temperature for $15 \mathrm{~min}$. and rapidly cooled. After centrifuging at $3000 \mathrm{~g}$ for $30 \mathrm{~min}$. at $0^{\circ}$ the supernatant fluid was fractionated between 30 and $50 \%$ saturation by the addition of a saturated solution of ammonium sulphate to which ammonia had been added so that a 1 in 100 dilution gave a $\mathrm{pH}$ reading of 6.5. The enzyme was dialysed overnight at $0^{\circ}$ against two changes of $20 \mathrm{vol}$. of water and refractionated between 30 and $42 \%$ saturation. The refractionated enzyme was dialysed in the same way and stored in polythene bottles at $-15^{\circ}$ until required.

Liver aldehyde dehydrogenase was prepared from an acetone powder of ox liver by alcohol fractionation at $12^{\circ}$ as described by Racker (1949), but, instead of being dialysed, it was freed from alcohol by passing through a column of Sephadex G-25 (Pharmacia Uppsala, Sweden) in water used according to the makers' instructions. The enzyme was precipitated by adding $8.8 \mathrm{~g}$. of ammonium sulphate to $30 \mathrm{ml}$. of solution at $0^{\circ}$. After centrifuging, the enzyme was redissolved in water and again passed through Sephadex G-25. The enzyme so prepared did not reduce NAD in the absence of added substrate.

Tissue preparations. Rat-liver slices $(0 \cdot 3 \mathrm{~mm}$. thickness) were prepared with a Mcllwain \& Buddle tissue chopper (H. Mickle, Gomshall, Surrey). They were suspended in Krebs-Ringer phosphate solution (Umbreit, Burris \& Stauffer, 1957). Selected slices were quickly drained on smooth filter paper (Whatman no. 50), weighed on a torsion balance and placed in ice-cold flasks containing KrebsRinger phosphate solution.

For measurement of respiration, rat-liver slices (195$205 \mathrm{mg}$. wet wt./Warburg flask) were incubated at $38^{\circ}$ for $1 \mathrm{hr}$. with $15 \mathrm{mg}$. of 2 -fluoroethanol or $0.5 \mathrm{mg}$. of sodium fluoroacetate in $3 \mathrm{ml}$. of Krebs-Ringer phosphate. Potassium hydroxide $(2 \mathrm{~N} ; 0.2 \mathrm{ml}$.) was placed in the centre well to absorb carbon dioxide.

To demonstrate the presence of fluoroacetate as a product of 2 -fluoroethanol oxidation, rat-liver slices ( $3 \mathrm{~g}$. wet wt.) were suspended in $30 \mathrm{ml}$. of Krebs-Ringer phosphate and shaken in air in a $125 \mathrm{ml}$. conical flask at $38^{\circ}$ for $2 \mathrm{hr}$. with $150 \mathrm{mg}$. of 2 -fluoroethanol. Proteins were precipitated by heating to boiling and filtered off. The filtrate was made alkaline to phenolphthalein with potassium hydroxide, and evaporated to dryness in vacuo on a rotating evaporator. The residue was taken up in $5 \mathrm{ml}$. of $\mathrm{N}$-sulphuric acid and extracted with ether continuously for $48 \mathrm{hr}$. A control flask with similar contents was treated in an identical manner except that it was heated to boiling immediately after the addition of 2-fluoroethanol. The ether extract (approx. $25 \mathrm{ml}$.) was dried overnight by the addition of $1 \mathrm{~g}$. of anhydrous sodium sulphate, and an excess of an anhydrous solution of diazomethane in ether was added. The solution was concentrated to about $0.1 \mathrm{ml}$. by carefully distilling off the ether. Gas-liquid chromatography (kindly carried out by Dr P. F. V. Ward) with argon and dinonyl phthalate on Celite as stationary phase at $75^{\circ}$ showed the presence of a compound in the experimental flask which was absent from the control and which had the same retention volume as authentic methyl fluoroacetate.

Guinea-pig-kidney particles were prepared and used as described by O'Brien \& Peters (1958a) with the exception that a Potter-Elvehjem homogenizer was used in place of a mortar and pestle.

Citrate estimation. Citrate was determined by the method of McArdle (1955) with the difference that the tubes were cooled before the addition of the bromate-bromide-vanadate mixture, and that the steps involving the removal of the acid layer, and washing and drying the light-petroleum layer, were omitted.

Animals. Rats used were albino Wistar strain maintained on Bruce \& Parkes (1949) diet number 41.

\section{RESULTS}

\section{Effect of 2-fluoroethanol in vivo}

The previous work with 2-fluoroethanol was carried out before the nature of the biochemical lesion induced by fluoroacetate had been shown to be the inhibition of aconitase by biosynthesized fluorocitrate (Peters, 1952).

The results of citrate analyses of tissues from rats poisoned by 2 -fluoroethanol are given in Table 1. The considerable accumulation of citrate induced by 2 -fluoroethanol supports the view that it is toxic by conversion into fluorocitrate.

The results show that, in vivo, heart is strongly affected by 2-fluoroethanol; moreover the rate of heart beat was appreciably lowered. K. J. Carpenter \& B. A. Kilby (unpublished work) showed 
Table 1. Effect of intraperitoneal injections of fluoroethanol on the accumulation of citrate in rats

Dose was $10 \mathrm{mg} . \mathrm{kg}$. Organs were removed immediately after death and extracted with ice-cold $8 \%$ trichloroacetic acid in ice-cold mortars.

\begin{tabular}{|c|c|c|c|c|c|}
\hline \multirow[b]{2}{*}{ Sex } & \multirow{2}{*}{$\begin{array}{l}\text { Body wt. } \\
\text { (g.) }\end{array}$} & \multirow{2}{*}{$\begin{array}{l}\text { Time elapsing between } \\
\text { injection and death } \\
\text { (hr.) }\end{array}$} & \multicolumn{3}{|c|}{ ( $\mu \mathrm{g} . / \mathrm{g}$. wet wt.) } \\
\hline & & & Heart & Liver & Kidney \\
\hline M & 208 & 2 & 688 & 33 & 154 \\
\hline $\mathbf{M}$ & 172 & 6 & 1340 & 371 & 1870 \\
\hline $\mathbf{M}$ & 178 & 7 & 1230 & 272 & 380 \\
\hline $\mathbf{F}$ & 179 & 51 & 1160 & 490 & 427 \\
\hline $\mathbf{F}$ & 117 & $5 \frac{1}{2}$ & 930 & 515 & 1670 \\
\hline $\mathbf{F}$ & 175 & $8 \frac{1}{2}$ & 738 & 150 & 501 \\
\hline $\mathbf{M}$ & 220 & Killed at 8 & 2215 & 1203 & 4200 \\
\hline $\mathbf{M}$ & 225 & Killed at 8 & 2780 & 1340 & 840 \\
\hline $\mathbf{M}$ & 230 & Killed at 8 & 2630 & 1661 & 4620 \\
\hline \multicolumn{6}{|c|}{ Control rats } \\
\hline $\mathbf{M}$ & 190 & - & 57 & 27 & 36 \\
\hline $\mathbf{M}$ & 170 & - & $202^{*}$ & $47^{*}$ & $93^{*}$ \\
\hline $\mathbf{F}$ & 127 & - & 107 & 28 & 40 \\
\hline $\mathbf{F}$ & 127 & - & 111 & 18 & 40 \\
\hline $\mathbf{F}$ & 135 & - & 105 & 34 & 38 \\
\hline
\end{tabular}

* This is the only case where such a high value has been obtained.

that an isolated heart perfused with 2-fluoroethanol at a concentration of $10 \mathrm{mg}$./ 1 . was unaffected after contact for $6 \mathrm{hr}$., whereas, under the same conditions, fluoroacetate greatly diminished both rate of beating and survival time.

Therefore, some tissue, other than heart, must metabolize 2-fluoroethanol to a compound capable of poisoning the heart. Since the liver has been shown to be the site of physiological oxidation of ethanol (Lundsgaard, 1938; Mirsky \& Nelson, 1939) it is likely to be the site of the oxidation of 2 -fluoroethanol to fluoroacetate.

However, the signs of 2 -fluoroethanol poisoning in rats after a dose of $10 \mathrm{mg} . / \mathrm{kg}$. by intraperitoneal injection differ in some respects from those caused by fluoroacetate. As with fluoroacetate there is a delay, in this case of $1 \mathrm{hr}$., before the onset of symptoms. The rats then show increasing lassitude, gradually becoming comatose, and die usually between 6 and $10 \mathrm{hr}$. after injection. In this Laboratory death from the same dosage of fluoroacetate usually occurs within $3 \mathrm{hr}$. of injection. Moreover, many rats die from injected 2 -fluoroethanol without showing any tonic convulsions regarded as typical of fluoroacetate poisoning (Peters, 1952).

\section{Effect of 2-fluoroethanol in vitro}

During incubation for $1 \mathrm{hr}$. without added substrate the oxygen uptake of rat-liver slices $(200 \mathrm{mg}$. wet wt.) was not inhibited by 2 -fluoroethanol (15 mg.) and only slightly (about $10 \%$ ) by sodium fluoroacetate $(0.5 \mathrm{mg}$.). Bartlett (1952) reported that 2-fluoroethanol began to inhibit oxygen uptake during a second hour of incubation. At the end of the incubation contents of duplicate flasks were combined, heated to boiling, cooled and
Table 2. Effect of a metabolic product of 2-fluoroethanol formed during incubation with rat-liver slices on citrate accumulation by guinea-pig-kidney-particle preparations

Rat-liver slices (200 mg. wet wt.) in $3 \mathrm{ml}$. of KrebsRinger phosphate were incubated at $38^{\circ}$ in air for $1 \mathrm{hr}$. with $15 \mathrm{mg}$. of 2 -fluoroethanol. The mixtures were heated to boiling, cooled and centrifuged. Samples $(0.3 \mathrm{ml}$.) were tested on kidney-particle preparations. Figures given are the average of two experiments both done in duplicate.

\section{Additions to kidney-particle preparations}

None

$$
\begin{gathered}
\text { Citrate } \\
\text { formed } \\
\text { ( } \mu \mathrm{g} . / \text { flask) }
\end{gathered}
$$$$
116
$$$$
944
$$$$
119
$$

Supernatant from liver slices incubated with no additions

Supernatant from liver slices incubated with 2-fluoroethanol

Fluoroethanol (1.5 mg.)
585

176 centrifuged. Samples of each supernatant were tested on guinea-pig-kidney preparations for their ability to induce citrate accumulation. The citrate content of $200 \mathrm{mg}$. of rat-liver slices even after incubation for $1 \mathrm{hr}$. with 2 -fluoroethanol, fluoroacetate or fluorocitrate is too low to be determined accurately. The amount of citrate added to the guinea-pig-kidney preparations in the $0.3 \mathrm{ml}$. sample of supernatant from the rat-liver slices would be at most $10 \mu$ g., i.e. negligible compared with the $585 \mu \mathrm{g}$. the sample caused to accumulate in guinea-pig-kidney preparations. The results (Table 2) show that 2-fluoroethanol alone has only a slight effect upon kidney preparations, but that 
the liver slices had changed 2-fluoroethanol to a compound capable of inducing considerable citrate accumulation. The slight rise of citrate concentration caused by the addition of 2 -fluoroethanol alone is not necessarily due to a slight conversion into fluorocitrate, but may well be a non-specific effect of a high concentration of an alcohol since a similar amount of ethanol has a similar effect (unpublished observation). Similar slight elevation of citrate concentration of guinea-pig-kidney preparations has been obtained with pyruvate (Liébecq \& Peters, 1949) and malonate (Peters \& Wakelin, 1957). The presence of fluoroacetate as a metabolic product of 2 -fluoroethanol in the supernatant from rat-liver slices was demonstrated as described in the Experimental section.

Two liver enzymes capable of oxidizing alcohols have been obtained in a pure form. Both these, catalase (Keilin \& Hartree, 1945) and alcohol dehydrogenase (Dalziel, 1958), were investigated.

Bartlett (1952) reported that a crude preparation of liver alcohol dehydrogenase could oxidize 2fluoroethanol but that, under his conditions, catalase could not do so.

Fig. 1 indicates that 2-fluoroethanol is a competitive inhibitor of ethanol oxidation by crystalline liver alcohol dehydrogenase with a $K_{i}$ of about

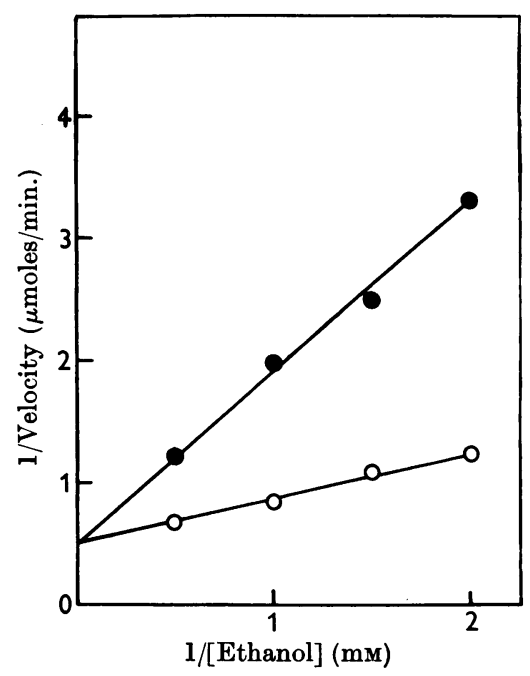

Fig. 1. Inhibition of liver alcohol dehydrogenase by 2 fluoroethanol. Complete system: NAD, 1 mg.; DL-cysteine, $0.5 \mathrm{mg}$; semicarbazide-HCl, $2 \mathrm{mg}$; sodium pyrophosphate, $0 \cdot 1 \mathrm{~m}$ adjusted to $\mathrm{pH} 9$ with $\mathrm{HCl}$; total volume, $3.3 \mathrm{ml}$. $\bigcirc$, Ethanol; $\bigcirc$, ethanol plus $5 \mathrm{mm-2}$-fluoroethanol. Dialysed liver alcohol dehydrogenase $(0.01 \mathrm{ml}$.) was added with stirring to start the reaction. Each point is the average of three determinations. The reaction velocity was measured by determining the rate of increase of extinction at $328 \mathrm{~m} \mu$ (Theorell \& Bonnichsen, 1951).
$2 \mathrm{~mm}$. Incubation of the enzyme with 2 -fluoroethanol for $10 \mathrm{~min}$. before the addition of ethanol did not increase the percentage inhibition. This showed that 2-fluoroethanol is not a substrate for the enzyme and that the inhibition is entirely competitive.

Nevertheless, Bartlett's observation that crude preparations of alcohol dehydrogenase could oxidize 2-fluoroethanol was confirmed. Ammonium sulphate fractionation of the supernatant from an homogenate of horse liver in water showed that some dehydrogenase activity for ethanol was precipitated at all concentrations of ammonium sulphate between 30 and $80 \%$ saturation. Dehydrogenase activity for 2-fluoroethanol was precipitated mainly between 30 and $50 \%$ saturation. Crystalline alcohol dehydrogenase is precipitated between 55 and $70 \%$ saturation (Dalziel, 1958).

It is apparent that there are two alcohol dehydrogenases in horse liver of differing specificity. The second alcohol dehydrogenase prepared as described in the Experimental section oxidizes 2-fluoroethanol at about $80 \%$ of the rate at which ethanol is oxidized under the same conditions. The enzyme is capable of using NADP but at a much lower rate than NAD (Table 3).

Catalase was shown by Keilin \& Hartree (1945) to use hydrogen peroxide, such as is formed during the oxidation of hypoxanthine by xanthine oxidase, to oxidize some alcohols to the corresponding aldehydes. 2-Fluoroethanol is oxidized by such a coupled system (Fig. 2). The apparent output of oxygen after $30 \mathrm{~min}$. in the absence of catalase is probably due to the slower decomposition of hydrogen peroxide in the absence of this enzyme. In the complete system oxygen continues to be taken up after hypoxanthine is completely oxidized, indicating that fluoroacetaldehyde is being oxidized by xanthine oxidase.

The solutions from this experiment were heated to boiling, cooled and centrifuged, and samples

Table 3. Relative rates of oxidation of ethanol and 2-fluoroethanol, and coenzyme specificity of a second liver alcohol dehydrogenase

The Warburg flasks contained $0.5 \mathrm{ml}$. of enzyme $\left(E_{280 \mathrm{~m} \mu}\right.$ $1 \cdot 1)$, phenazine methosulphate $(100 \mu \mathrm{g}$. in $0.1 \mathrm{ml}$.), potassium phosphate buffer $(0.5 \mathrm{M} ; \mathrm{pH} 7.2 ; 0.5 \mathrm{ml}$.), NAD or NADP (1 mg. in $0.1 \mathrm{ml}$.) neutralized with $\mathrm{NaOH}$ to $\mathrm{pH} 7.2$ and water to $1.9 \mathrm{ml}$. The flasks were incubated at $38^{\circ}$ for $30 \mathrm{~min}$. to reduce endogenous substrates before substrate solutions $(0.1 \mathrm{ml}$.) were tipped in. Activities are expressed as $\mu$ l. of $\mathrm{O}_{2}$ taken $\mathrm{up} / \mathrm{hr}$.

Coenzyme

\begin{tabular}{lrcc}
\multicolumn{1}{c}{ Substrate } & None & NAD & NADP \\
None & 2 & 10 & 9 \\
Fluoroethanol $(100 \mathrm{~mm})$ & 4 & 306 & 33 \\
Ethanol $(100 \mathrm{~mm})$ & $\mathbf{1 6}$ & $\mathbf{3 7 4}$ & 91
\end{tabular}


tested on a guinea-pig-kidney preparation for their ability to induce citrate accumulation. Table 4 shows clearly that oxidation by catalase, and possibly further oxidation of the aldehyde by xanthine oxidase, converts 2 -fluoroethanol into a compound that is toxic to such preparations.

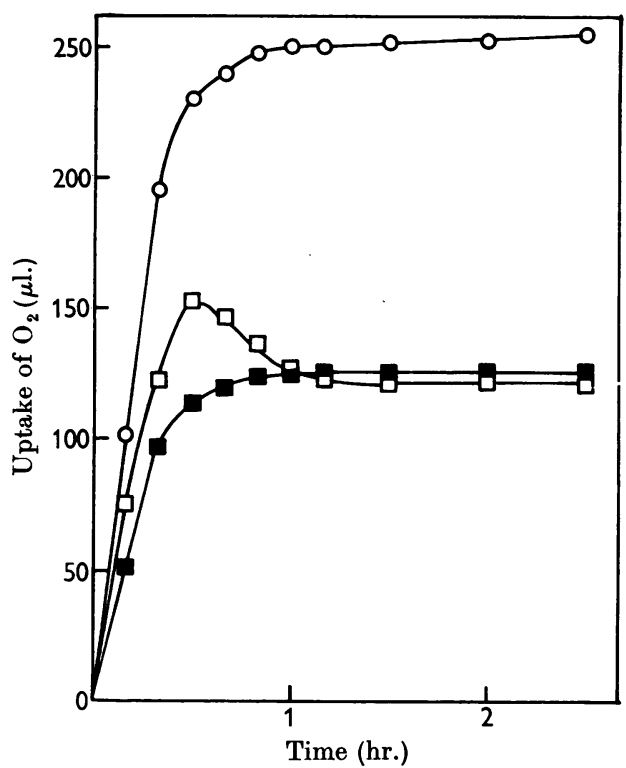

Fig. 2. Oxidation of fluoroethanol by catalase and hydrogen peroxide. Complete system: crude xanthine oxidase, $50 \mathrm{mg}$; hypoxanthine, $0.75 \mathrm{mg}$. (to provide $\mathrm{H}_{2} \mathrm{O}_{2}$ ); catalase, $1 \mathrm{mg}$.; 2 -fluoroethanol, $13.9 \mathrm{mg}$.; potassium phosphate buffer $(0 \cdot 1 \mathrm{~m}$; pH 7.8), $3 \mathrm{ml}$. $\bigcirc$, Complete system; $\square$, catalase omitted; $\mathbf{n}, 2$-fluoroethanol omitted. Each point is the average of four determinations.

Table 4. Effect of fluoroethanol after oxidation by catalase on citrate accumulation by guinea-pig-kidneyparticle preparations

The incubated mixtures from the experiment described in Fig. 2 were heated to boiling and the precipitated protein removed by centrifuging. The complete system consisted of catalase (1 mg.), xanthine oxidase (50 mg.), 2 -fluoroethanol (13.9 mg.), hypoxanthine $(0.75 \mathrm{mg}$.), potassium phosphate buffer $(0 \cdot 1 \mathrm{~m} ; \mathrm{pH} 7 \cdot 8 ; 3 \mathrm{ml}$.). Figures given are the average of two experiments both done in duplicate.

Additions to kidney-particle
preparations

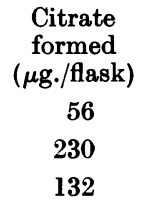

Sodium fluoroacetate (50 $\mu \mathrm{g}$.)

405

lase but no fluoroethanol

Supernatant from mixture with cata405 lase and fluoroethanol

Supernatant from mixture with fluoroethanol but no catalase
Fluoroacetaldehyde formed from 2-fluoroethanol by catalase, by using glucose and glucose oxidase as the source of hydrogen peroxide, was found to be a substrate for liver aldehyde dehydrogenase. Crude glucose oxidase (24 mg.) and catalase (1 mg.) were incubated in $\mathrm{M}$-phosphate buffer, $\mathrm{pH} 7 \cdot 0$, at $38^{\circ}$ in Warburg apparatus with glucose (1 mg.) and 2-fluoroethanol (12.8 mg.) in the side arm. Total volume was $2 \cdot 3 \mathrm{ml}$. The reaction was complete in $15 \mathrm{~min}$. and the oxygen uptake was $115 \mu \mathrm{l}$., where glucose was omitted $2 \mu \mathrm{l}$., and where 2 -fluoroethanol was omitted $62 \mu \mathrm{l}$. The extra oxygen uptake due to the presence of the 2-fluoroethanol (53 $\mu$ l.) indicated the formation of $4 \cdot 74 \mu$ moles of fluoroacetaldehyde, i.e. $2.06 \mu \mathrm{moles} / \mathrm{ml}$. Samples $(0.1 \mathrm{ml}$.) from each of the combined contents of duplicate flasks were added to $1 \mathrm{~cm}$. spectrophotometer cuvettes containing $0 \cdot 1 \mathrm{ml}$. of NAD solution (10 mg./ml.), $0.05 \mathrm{ml}$. of liver aldehyde dehydrogenase $\left(E_{280 \mathrm{~m} \mu} 32.2\right)$ and $3.0 \mathrm{ml}$. of $0.2 \mathrm{M}$-potassium glycinate, $\mathrm{pH} 9 \cdot 3$. The formation of $\mathrm{NADH}_{2}$ was followed at $340 \mathrm{~m} \mu$.

The samples from Warburg flasks from which 2-fluoroethanol or glucose had been omitted caused a steady rate of formation of $\mathrm{NADH}_{2}$ of $13.1 \times$ $10^{-10} \mathrm{~mole} / \mathrm{min}$. The sample from the Warburg flasks which contained the complete system, i.e. containing fluoroacetaldehyde, gave an initial rate of $\mathrm{NADH}_{2}$ formation of $471 \times 10^{-10} \mathrm{~mole} / \mathrm{min}$., which eventually fell sharply to the same rate as the two controls, i.e. $13.1 \times 10^{-10} \mathrm{~mole} / \mathrm{min}$. By extrapolating the final rate of formation of $\mathrm{NADH}_{2}$ to the time of addition of sample it was possible to calculate the total amount of $\mathrm{NADH}_{2}$ formed by complete oxidation of the fluoroacetaldehyde contained in the sample. This gave a value of $0.22 \mu \mathrm{mole} / 0 \cdot 1 \mathrm{ml}$., which is to be compared with $0.206 \mu \mathrm{mole} / 0.1 \mathrm{ml}$. calculated from the extra oxygen uptake in the Warburg flasks caused by the presence of 2-fluoroethanol. The corrected rate of oxidation of fluoroacetaldehyde, $458 \times 10^{-10} \mathrm{~mole} /$ min., was greater than the rate of oxidation of acetaldehyde $(0.18 \mu \mathrm{mole}), 303 \times 10^{-10} \mathrm{~mole} / \mathrm{min}$. Because of the very low $K_{m}$ of aldehydes for liver aldehyde dehydrogenase (Racker, 1949), these figures represent the relative $V_{\max }$ for the two substrates.

\section{DISCUSSION}

It is clear from the results presented that 2-fluoroethanol is toxic by a lethal synthesis of fluorocitrate, and that the liver is capable of bringing about the initial conversion into fluoroacetaldehyde, by a second alcohol dehydrogenase and by catalase, and the further oxidation to fluoroacetate by liver aldehyde dehydrogenase.

It is the hope of those studying fluorine-substituted metabolites that they may give information 
about pathways of normal metabolism (O'Brien \& Peters, 1958b). It is gratifying that the investigation of the metabolism of 2 -fluoroethanol should show the presence of a second alcohol dehydrogenase in liver.

\section{SUMMARY}

1. 2-Fluoroethanol, known to be toxic to rats, causes a considerable rise in tissue concentrations of citrate.

2. Guinea-pig-kidney-particle preparations are unaffected by 2 -fluoroethanol, which, however, is converted by incubation with liver slices or by coupled oxidation by catalase into a compound capable of inducing citrate in the particle preparations.

3. Rat-liver slices oxidize 2-fluoroethanol to fluoroacetate, identified as the methyl ester by gasliquid chromatography.

4. 2-Fluoroethanol is not a substrate for crystalline horse-liver alcohol dehydrogenase, and competitively inhibits the oxidation of ethanol by this enzyme.

5. A second liver alcohol dehydrogenase of different specificity readily oxidizes 2-fluoroethanol with nicotinamide-adenine dinucleotide, and to a lesser extent nicotinamide-adenine dinucleotide phosphate, as coenzymes.

6. Fluoroacetaldehyde is oxidized one and a half times as fast as is acetaldehyde by liver aldehyde dehydrogenase.

The author is deeply indebted to Sir Rudolph A. Peters, F.R.S., for his interest and advice. Thanks are due to Miss P. A. Ivall and Mrs M. A. Davies for skilled technical assistance and to the Wellcome Trust for a Research Fellowship during part of this work.

\section{REFERENCES}

Bartlett, G. R. (1952). J. Pharmacol. 106, 464.

Bonnichsen, R. K. \& Wassen, A. M. (1948). Arch. Biochem. $18,361$.

Bruce, H. M. \& Parkes, A. S. (1949). J. Hyg., Camb., 47, 201.

Dalziel, K. (1958). Acta chem. scand. 12, 459.

Keilin, D. \& Hartree, E. F. (1945). Biochem. J. 39, 293.

Liébecq, C. \& Peters, R. A. (1949). Biochim. biophys. Acta, 3, 215.

Lundsgaard, E. (1938). Johns Hopk. Hosp. Bull. 63, 15.

McArdle, B. (1955). Biochem. J. 60, 647.

McCombie, H. \& Saunders, B. C. (1946). Nature, Lond., $158,382$.

Mirsky, I. A. \& Nelson, N. (1939). Amer. J. Physiol. 126, 587.

O'Brien, R. D. \& Peters, R. A. (1958a). Biochem. Pharmacol. $1,3$.

O'Brien, R. D. \& Peters, R. A. (1958b). Biochem. J. 70, 188.

Pattison, F. L. M., Howell, W. C., McNamara, A. J., Schneider, J. C. \& Walker, J. F. (1956). J. org. Chem. 21, 739.

Peters, R. A. (1952). Proc. Roy. Soc. B, 139, 143.

Peters, R. A. \& Wakelin, R. W. (1957). Biochem. J. 67, 280.

Racker, E. (1949). J. biol. Chem. 177, 883.

Saunders, B. C., Stacy, G. J. \& Wilding, I. G. E. (1949). J. chem. Soc. p. 773.

Schrader, G. (1935). I. G. Leverkusen German Patent J. 52803, 11 July.

Singer, T. P. \& Kearney, E. B. (1957). Meth. biochem. Anal. 4, 307.

Swarts, F. (1914). Bull. Acad. Belg. Cl. Sci. p. 7.

Theorell, N. \& Bonnichsen, R. (1951). Acta chem. scand. $5,1105$.

Umbreit, W. W., Burris, R. M. \& Stauffer, J. F. (1957). Manometric Techniques, p. 149. Minneapolis: Burgess Publishing Co.

Biochem. J. (1962) 82, 134

\title{
The Effect of Dinitrophenol and Amytal on the Reduction of Acetoacetate in the Presence of Succinate
}

\author{
By H. A. KREBS AND L. V. EGGLESTON \\ Medical Research Council Unit for Research in Cell Metabolism, Department of Biochemistry, \\ University of Oxford
}

(Received 21 July 1961)

Chance \& Hollunger $(1957,1960,1961)$, Chance \& Hagihara (1960), Chance (1961 $a, b)$, Chance \& Fugmann (1961), Klingenberg, Slenczka \& Ritt (1959), Azzone, Ernster \& Klingenberg (1960), Azzone \& Ernster $(1961 a, b)$, and Klingenberg \& Schollmeyer $(1960,1961)$ have put forward the view that the reduction of diphosphopyridine nucleotide observed on addition of succinate to mitochondria involves a reversal of oxidative phosphorylation. Evidence in favour of another mechanism, a competitive inhibition of the oxidation of reduced diphosphopyridine nucleotide by succinate, was put forward by Birt \& Bartley (1960), and by Kulka, Krebs \& Eggleston (1961) 